Vol. 3, No. 1, 2021

Research Article

\title{
Factors Influencing Employee Engagement in a Financial Institution
}

\author{
Hadziroh Ibrahim ${ }^{*}$, Mohd Hadi Alya Mohd Rodzi² and Md.Lazim Mohd Zin ${ }^{1}$ \\ ${ }^{1}$ Universiti Utara Malaysia, Sintok, Kedah, Malaysia. \\ hadziroh@uum.edu.my; lazim@uum.edu.my \\ 2iSYNERGY Sdn Bhd, Kuala Lumpur, Malaysia \\ hadi@isynergy.my \\ *Correspondence: hadziroh@uum.edu.my
}

Received: 29 $9^{\text {th }}$ November 2020; Accepted: $19^{\text {th }}$ January 2021; Published: $1^{\text {st }}$ February 2021

Abstract: The purpose of this paper is to determine the relationship between transformational leadership, employee voice, training and development, and employee engagement among employees in a financial institution in Kuala Lumpur, Malaysia. Quantitative data were collected using survey design, for which 248 employees responded. These employees were sourced from the financial institution. Based on multiple linear regression analyses, this study finds that transformational leadership, training and development are positively related to employee engagement. However, employee voice has no significant influence on employee engagement, which is employee engagement is not influenced by employee voice. The findings of this study offered useful knowledge and bright insights for future researchers concerning the scope of the study. In the matter of practice, the findings have contributed to the management of the banking sector in which they can apply two independent variables such as transformational leadership and training and development to enhance employee engagement in a financial institution.

Keywords: Transformational Leadership; Employee Voice; Training and Development; Financial Institutions; Social Exchange Theory

\section{Introduction}

According to Aon Hewitt Trends in Global Employee Engagement (2018) survey on "trends in international employee engagement", Malaysia is slowly improving in terms of employee engagement, reaching to $63 \%$ in 2018. However, the country nevertheless ranks among the lowest in the Asia Pacific, which is falling behind its neighbouring nations like Indonesia and the Philippines. This shows that employee engagement in the international aspect has to deal with high challenges to preserve it within the organization.

Therefore, engagement by the employee is seen as the key to efficiency. This is because employees who are fully engaged with their job and organization will enhance the unity at the workplace and motivate other employees. These employees will produce better opinions and ideas for organizational development. In the current situation, some of the companies have limited their hiring in recent years because of the slow economic recovery and uncertain economic conditions. In this case, some companies have made employee engagement an important aspect of increasing workload for the existing staff. Besides, retaining the best and excellent employees has become crucial as much as recruiting a new talent of employees. So, the organization can address employee engagement as the potential initiative to retain the best talent.

Hadziroh Ibrahim, Mohd Hadi Alya Mohd Radzi and Md.Lazim Mohd Zin, "Factors Influencing Employee Engagement in a Financial Institution", Annals of Contemporary Developments in Management \& HR (ACDMHR), Print ISSN: 2632-7686, Online ISSN: 2632-7694, pp. 33-42, Vol. 1, No. 1, $1^{\text {st }}$ February 2021, Published by International Association of Educators and Researchers (IAER), DOI: 10.33166/ACDMHR.2021.01.004, Available: http://acdmhr.theiaer.org/archive/v3/v3n1/p4.html. 
Nowadays, employee engagement has considerably transformed a top priority of excellence for the top management by engaging their employees in attaining the goal or objective within a respective organization. In line with that, Sibanda, Muchena, and Ncube (2014) affirm that employee engagement increases the organizational creativity, efficiency and performance, while reducing the recruitment and retention costs. According to Song et al. (2012), employee engagement has a positive impact on individual performance, knowledge creation that later brings financial returns.

In Malaysia's context, studies on employee engagement have been conducted in various healthcare, public and private sectors (Shee Mun, Suhaimi, Abdullah, Rahman \& Mat, 2013; Ganesan, Azli \& Fageeh, 2017; Mansor, Jaharudin \& Nata, 2018). However, there are limited studies on employee engagement within the banking sector in Malaysia. Therefore, the authors in the current study have attempted to examine in the financial sector and assess how employee engament is influenced by factors such as transformational leadership, employee voice and training and development.

\section{Literature Review}

\subsection{Employee Engagement}

Universally, employee engagement has been defined by Kahn (1990) as people in the company who works by demonstrating themselves with high physical, cognitive, and emotional immersion. Firstly, the physical dimensions of employee engagement include the physical energy generated by employees to accomplish their working tasks. Secondly, the cognitive aspects of employee engagement focus on employees with respect to organizational values, other employees, and working conditions. Thirdly, the last factor is an emotional factor, including how employees feel towards all of these three aspects which explains either they have a positive or negative attitude towards their work, superiors and organization as a whole.

Likewise, Luthans and Peterson (2002) suggest that employees who engage in the organization by working with a good sense of mind tend to carry out their work by achieving the organization's aims and goals. Besides that, Sak (2006) has exclaimed that engagement among employees comes from a multidimensional context. This category includes points from previous literature that indicated employee engagement from cognitive, emotional, and behavioural elements (Ahmed, 2019; Kahn, 1990; Maslach, Schaufeli and Leiter, 2001; Harter, Schmidt \& Hayes, 2002; Saks, 2006). Other than that, Saks (2006) affirmed a simple theoretical approach that can be used to grip a thorough understanding of employee engagement, which is the Theory of Social Exchange (SET). In other words, SET is the way whereas an individual can compensate his or her organization by examining his or her level of employee engagement. Therefore, the authors believe employees may want to respond to various resources that organizations provide them with.

Furthermore, Bakker and Schaufeli (2008) attest that employee engagement is a behavioural situation in which employees show a strong belief in the organizational achievement by meeting the expectations to exceed the requirements of the working tasks. Similarly, employee engagement is a specific concept that encompasses different forms of engagement, such as engagement traits, psychological state of engagement, and engagement behavioural. All of these terms have different meanings in such as proactive personality is a trait of engagement, participation is a psychological state of engagement, and behaviour of organizational citizenship is behavioural engagement (Macey \& Schneider, 2008). In a similar vein, Sanneh and Taj (2015) justified that employee engagement can be described as how workers are fully committed to performing their work physically, emotionally, and cognitively. Other than that, Shahid (2019) also clarified that employee engagement refers to the communication and transmission between employer and employees with creating the trust of team members in the organizational culture. Therefore, this study is supported by the assertions of Bakker and Schaufeli (2008), explaining that employee engagement is defined as employee interest on working in an organization that could be used to predict the links between transformational leadership, employee voice and training, and development. 
Various independent variables have been explored previously in which lies the connection of employee engagement in past research. For example, Anitha (2014) revealed that there are multiple factors affecting employee engagement, including career development, employee relationship, training, leadership, team, and compensation. Similarly, AlZgool et al. (2020) recently found the significance of psychological resources to boost engagement. Other than that, a certain key factor of employee engagement includes workplace well-being, organizational policies, procedures, structures, and systems. Significantly, the study discloses that when employees get engaged in the organization, their performance will improve. Thus, results indicated that the relationship between employee engagement and employee performance is proven to be strongly significant.

\subsection{Transformational Leadership and Employee Engagement}

Bass and Riggio (2006) asserted that transformational leadership is a leadership style which encourages and inspires followers. Here, the leader helps the employees achieve incredible results rather than developing leadership abilities independently. Transformational leadership refers to a leader who motivates and influences followers through interaction and works to develop and expand their capabilities into leadership skills through empowering individuals and groups (Avolio \& Bass, 2004). According to Gibson et al. (2012) and Pahi et al. (2015), transformational leadership is a leader who pushes his or her followers to go beyond direct self-interest through the idealization of charisma, inspiration, intellectual stimulation or individualization, which predicts commitment. Accordingly, transformational leadership raises leader`s maturity, ideas and concerns about achievement, personal recognition, and caring for the well-being of others, society, and organization.

Similarly, transformative leaders are known to inspire and motivate followers to reach more than initially planned results by reinventing the entire organization's philosophy, systems, and culture. This study was supported by Raffety and Griffin (2004), which referred to transformational leadership as a leader that can transform subordinates into creative beings to achieve individual and organizational goals efficiently. This statement of clarification was examined to predict the links within the employee engagement.

A previous study conducted by Bui, Zeng and Higgs (2017) upholds that transformational leadership has a positive relationship to employee engagement. Their study involved 691 employees who already worked with a line manager in China. In this study setting, the findings revealed that transformational leadership impacts the level of engagement among employees. Hence, transformational leaders can systematically work for long-term organizational growth. Hence, organizations will succeed if they adopt the development programs to create transformational leadership ability within their leader communities.

Furthermore, in the context of the scope of the study, previous studies on commercial banks in Ghana sampling 315 employees reported a positive relationship between the dimensions of transformational leadership and job satisfaction (Puni, Mohammed, \& Asamoah, 2018). Thus, the following hypothesis is proposed:

H1: There is a positive relationship between transformational leadership and employee engagement.

\subsection{Employee Voice and Employee Engagement}

Employee voice is an employee's involvement and interaction with a job working by providing the ideas and opinions to help the organization achieve the target and objectives they have created. This elucidation means that an employee's voice could encourage employees to focus on improving their working processes and sorting out their thoughts and opinions accordingly as accordance to companies' regulations by aiming for their performance goals (Van Dyne \& Le Pine, 1998). Likewise, employee voice provides discretion of information to improve individual organization's functioning since knowledge and information can challenge and threaten the status quo and authority in the organization (Detert \& Burris, 
2007). Similarly, Tangirala, Kamdar, Venkataramani, and Parke (2013) resolved that employees' voice is defined as a person who expresses their views, concerns, or ideas on challenging but constructive employment-related issues. Reissner and Pagan (2013) simplified that employees whom able to deliver their voice in the company will secure them to feel respected, and willingly commit as much as beyond needed to their work hence raise employee engagement.

According to Rees, Alfes and Gatenby (2013), these researches have declared the relationship between both senior management and employee line manager, whereas employee voice has a relationship with employee engagement mediated by trust. Given that, there has been no research that indicates a voice specifically linked to employee engagement. However, other broader literature has explored the role of employee involvement and voice mechanism in encouraging employee engagement. In other words, as followed by Van Dyne and LePine (1998), employee voice refers to employee involvement in suggesting changes in the organization.

The statement is supported by previous studies that accommodate several factors related to high engagement among workers following employee involvement in related work (Purcell et al., 2003). Despite that, minimal research on employee voice and employee engagement is available. It is declared by Rees et al. (2013) also in which these researchers described a significant lack of literature on the direct relationship between the voice of employees and employee engagement within an organization. Thefore, the following hypothesis is proposed:

H2: There is a positive relationship between employee voice and employee engagement.

\subsection{Training and development and Employee Engagement}

Delery and Dotty (1996) have accumulated training and development as the creation of programs where specialized knowledge, skills, and abilities are given to employees to enhance their performance among their existing roles, providing them with learning opportunities and arising of furthering their growth. According to Aguinis and Krager (2009), training and development gives advantages to individuals, teams, organizations, and communities and provides individual or organizational advantages for the economic development of the nation. The authors noted that cognitive and interpersonal skills are the two most important training programs, followed by skills or psychological tasks. Tannenbaum et al. (2012) have emphasized that the conduct of training and development activities are instrumental to excellence, innovation, productivity, process improvement, and the achievement of its objectives amongst organizations. Aguinis and Kraeger (2009) also support recognizing training and development as a crucial entity to bring the best from the employees.

Liekwise, Anitha (2014) also proclaimed that training and career development positively impact employee engagement. The author recommended that training should be part of organizational policy. Equally, Shuck and Wollard (2010) have also indicated a positive relationship between learning opportunities and employee engagement. Afroz (2018) recently emphasized on employee engagement in Bangladesh's banking sector. The study included 150 staff from 14 banks based in the Tangail region of Bangladesh. The results revealed that most respondents regularly received training that nurtured a feeling of belonging, commitment, and fulfillment. Siddiqui and Sahar (2019) and Ahmed et al. (2017) also examined the effect of training, development, and communication on employee engagement in the banking sector of Pakistan. Similarly, training is also reported being significant in improving employee outcomes in the service sector in general (Chadha, 2018). Thus, the following hypothesis is proposed:

H3: There is a positive relationship between training and development and employee engagement.

According to Saks (2006), the principle of social exchange has provided the psychological framework to understand why workers want to be more or less involved in their job and organization. In addition, other researchers supported the theory of social exchange to describe employee engagement (Kahn, 1990; Maslach, Schaufelli, \& Leiter, 2001; Saks, 2006). As per Saks (2006), Social Exchange Theory (SET) is created 
from a progression perspective which is best to explain social exchanges between employees and organizations in terms of their behaviors and outcomes.

Cropanzano and Mitchell (2005) demonstrated the social exchange theory as a relationship that grows from confidence and mutual loyalty berween the two parties. This implied that one party takes steps to respond to the other due to trade or repayment rules. For example, when individuals receive some resources from the organization such as training, growth, leadership, they feel responsible for giving feedback, taking positive actions, and repaying to the organization. According to Cropanzano and Mitchell (2005), SET exists if the rules of exchange bind both parties, the result has become a greater trust, loyal relationship, and shared loyalty between them. For example, the organization provided training for the employee to improve their skills and abilities in helping with their job responsibilities. For return, the employees need to guarantee the commitment by engaging themselves to increase trust, loyalty, and engagement among employer and employee. Therefore, in this study, we test three variables using SET theory, including transformational leadership, employee voice, and training and development, to determine employee engagement.

\section{Research Method}

\subsection{Population and Sample}

Respondents of the present study included executive and non-executive employees in a financial institution in Kuala Lumpur, Malaysia. A convenience sampling technique was used to choose respondents in the study. This sampling technique was appropriate because it is arguably the best way to immediately and cost-effectively obtain some fundamental information (Sekaran \& Bougie, 2016).

\subsection{Measurement}

Employee engagement was measured by a 17-item scale from Schaufeli, Salanova, Gonzalez-Roma and Bakker (2002), that consists of three dimensions such as vigor (six items), dedication (five items) and absorption (six items). The scale is validated across many geographical and occupation regions (e.g., Ahmed et al., 2016; Shimazu et al., 2008). The results indicated a high value of internal consistency of vigor (0.84), dedication (0.86) and absorption (0.82). The study adapted a four-dimensional 15-items scale from Rafferty and Griffin (2004) for transformational leadership. These 15 items catered to 5 different dimensions including vision, inspirational communication, intellectual stimulation, supportive leadership, and personal recognition. A past study by Balwant, Mohammed, and Singh (2019) had used this instrument with attained Cronbach alpha value result of 0.92. Employee voice was tested adapting the 6-item scale from Botero and Van Dyne (2009). Previous researchers such as Van Dyne and Le Pine (1998) have used this instrument, reporting a Cronbach Alpha of 0.89 for self, 0.96 for peer and 0.94 for supervisor. Another study by Rees, Alfes, and Gatenby (2013) indicated the Cronbach Alpha coefficient value of 0.90 for this scale. Accordingly, training and development was tested adapting the 4-item scale by Delery and Doty (1996) who reported a cronbach alpha of 0.83 for scale. Aktar and Pangil (2018) had also used this instrument for their studies with a reported Cronbach Alpha value of 0.88 .

\section{Results}

\subsection{Respondent Profile}

A total of 300 questionnaires were distributed, and 259 employees responded (response rate was 86 percent). Another 41 questionnaires were unreturned. Out of these 259 questionnaires, 50.2 percent were male respondents, and the rest were female respondents ( 49.8 percent); 86.5 percent were Malay; and majority of the respondents (37.5 percent) aged between 31-40 years. For work positions, 68.7 percent of 
respondents were executives and mostly serving the organization for more than 5 years. Table 1 provides detailed information on the respondents` profile.

Table 1. Respondent Profile

\begin{tabular}{|c|c|c|}
\hline Demographic & Frequency & Percentage $(\%)$ \\
\hline \multicolumn{3}{|l|}{ Gender } \\
\hline Male & 130 & 50.2 \\
\hline Female & 129 & 49.8 \\
\hline \multicolumn{3}{|l|}{ Age } \\
\hline 20-30 years old & 90 & 34.7 \\
\hline $31-40$ years old & 97 & 37.5 \\
\hline $41-50$ years old & 71 & 27.4 \\
\hline $51-60$ years old & 1 & 0.38 \\
\hline \multicolumn{3}{|l|}{ Race } \\
\hline Malay & 224 & 86.5 \\
\hline Chinese & 28 & 10.8 \\
\hline Indian & 7 & 2.7 \\
\hline Other & 0 & 0 \\
\hline \multicolumn{3}{|l|}{ Marital Status } \\
\hline Single & 90 & 34.7 \\
\hline Married & 169 & 65.3 \\
\hline Divorced & 0 & 0 \\
\hline \multicolumn{3}{|l|}{ Academic Qualifications } \\
\hline SPM/STPM/Equivalent & 1 & 0.4 \\
\hline Diploma/Equivalent & 188 & 72.6 \\
\hline Bachelor's Degree/Equivalent & 66 & 25.5 \\
\hline Master's Degree/Equivalent & 4 & 1.5 \\
\hline Doctoral Degree (PhD) & 0 & 0 \\
\hline \multicolumn{3}{|l|}{ Job Category } \\
\hline Executive & 178 & 68.7 \\
\hline Non-Executive & 81 & 31.3 \\
\hline \multicolumn{3}{|l|}{ Years of Service } \\
\hline Below 5 years & 99 & 38.2 \\
\hline 6 to 10 years & 90 & 34.7 \\
\hline $11-15$ years & 55 & 21.2 \\
\hline More than 16 years & 15 & 5.8 \\
\hline \multicolumn{3}{|l|}{ Working Experience } \\
\hline Below 5 years & 78 & 30.1 \\
\hline 6 to 10 years & 81 & 31.3 \\
\hline $11-15$ years & 39 & 15.1 \\
\hline More than 16 years & 61 & 23.6 \\
\hline
\end{tabular}

\subsection{Pearson Correlation}

To examine the direction of relationships between the variables, Pearson's correlation analysis was employed. Table 2 provides the correlation analysis outputs for the study. It shows that transformational leadership correlates with employee engagement $(r=0.502)$. In comparison, employee voice resulted a correlation of $\mathrm{r}=-0.361$. Lastly, training and development also correlated with employee engagement $(\mathrm{r}=0.630)$. Thus, as results being analysed according to Guildford (1973) interpretation, some independent variables such as transformational leadership and training and development have a high relationship with employee engagement meanwhile employee voice has low relationship. 
Table 2. Pearson Correlation Analysis

\begin{tabular}{lllll}
\hline Variable & TL & EV & TD & EE \\
\hline Transformational Leadership (TL) & 1 & & & \\
Employee Voice (EV) & $0.403^{* *}$ & 1 & & \\
Training and Development (TD) & $0.320^{* *}$ & $0.374^{* *}$ & 1 & $0.630^{* *}$ \\
Employee Engagement (EE) & $0.502^{* *}$ & $0.361^{* *}$ & 1 \\
\hline
\end{tabular}

\subsection{Multiple Regression}

Table 3 shows the $\mathrm{R}$ square of 50 percent. It means that only 50 percent variance of employee engagement can be explained by the variables of the study and 50 percent from other that are not included in this study. Multiple regression analysis was used to examine the relationship between transformational leadership, employee voice, training and development, and employee engagement. Results in Table 4 show that two independent variables have a significant relationship with the dependent variable, which are transformational leadership with a p-value of $0.00(\mathrm{p}<0.05)$ and training and development with a $\mathrm{p}$-value of $0.00(p<0.05)$. While employee voice has no significant relationship with the dependent variable $(p>0.05)$. Therefore, $\mathrm{H} 1$ and $\mathrm{H} 3$ were accepted.

Table 3. Model Summary

\begin{tabular}{llll}
\hline $\mathbf{R}$ & $\mathbf{R}$ Square $\left(\mathbf{R}^{2}\right)$ & Adjusted R Square & Std, Error of the Estimate \\
\hline $0.707^{a}$ & .500 & .494 & .41694 \\
\hline a. & Predictors: (Constant), Transformational Leadership, Employee Voice and Training and Development \\
b. & Dependent Variable: Employee Engagement.
\end{tabular}

Table 4. Multiple Linear Regression Analysis

\begin{tabular}{llllll}
\hline & \multicolumn{2}{l}{$\begin{array}{l}\text { Unstandardized } \\
\text { Coefficients } \\
\text { B }\end{array}$} & $\begin{array}{l}\text { Standardized Error } \\
\text { Soefficients } \\
\text { Beta }\end{array}$ & t & \\
Model & .263 & .356 & & & Sig. \\
\hline (Constant) & .580 & .089 & .323 & -.739 & .461 \\
Transformational Leadership & .053 & .067 & .040 & 6.538 & .000 \\
Employee Voice & .443 & .042 & .512 & .793 & .428 \\
Training Development & & & & 10.491 & .000 \\
\hline
\end{tabular}

a. $\mathrm{N}=259$

b. Dependent Variable: Employee Engagement.

\section{Discussion and Conclusion}

Firstly, the proposed research objective is to determine the relationship between transformational leadership and employee engagement. Findings from multiple regression analyses (refer to Table 6) show a significant relationship between transformational leadership and employee engagement as supported by $\mathrm{p}$-value $(\mathrm{p}=0.000)$ at alpha 0.05 . With this interpretation, transformational leadership does indeed affect employee engagement, hence supporting prior research.

Align with recent findings of the previous studies, it is suggested that transformational leadership can enhance employee engagement (Balwant, Mohammed, \& Singh, 2019). The researchers affirmed that there is a strong positive relationship between transformational leadership and employee engagement. Balwant et.al (2019) addressed that a clear vision will help employees achieve organizational goals and appreciate the importance of their commitment to achieving objectives and vision. Next, inspirational communication may include employees through actions exhibited by a leader in the organization. The strong inspirational attitudes will be distributed to employees through the leader's good attitude and behaviour. This is because 
a leader who involves intellectual stimulation to engage his or her employees in thought and finding the right solutions to organizational issues.

Secondly, the research objective is to determine the relationship between employee voice and employee engagement. The multiple regression analysis results have concluded that the employee voice has no significant influence on employee engagement with a significant amount of $p=0.428(p>0.05)$. This justification defines that employee engagement is not influenced by employee voice. The analysis is contradicted by a study of Jha, Potnuru, Sareen, and Shaju (2019) in which these researchers found employee voice to own a positively significant relationship with employee engagement.

Lastly, the final research objective was to determine the relationship between training and development with employee engagement. The result from multiple regression analysis shows that training and development significantly influence employee engagement with a significant amount of $\mathrm{p}=0.000$ $(\mathrm{p}<0.005)$. This supported the fact that training and development uphold positive relations to employee engagement. Result reported was similar to a study by Afroz (2018) whereby the findings revealed that most of the author's respondents had engaged regularly in training programs provided by their employer banks. Through the participation at the training program, many of these qualified employees think they are more committed, fulfilled, and inspired by the organization's training. Siddiqui and Sahar (2019) recently have studied the impact of training, development, and communication on employee engagement. Relevant to understanding the findings, it showed a positive effect on training and development as well as internal communication on employee engagement.

In terms of the impact of the study, the researcher believes findings from this study can be used for future improvement and development, especially in the banking sector in Malaysia, which aspire to focus on employee engagement. Universally, the banking industry is known as a service-oriented industry where employees' work and interaction purely demand direct involvement with customers or clients they must meet. Therefore, this study has discovered several implications on the theoretical and practitioners in organizations existing in Malaysia.

Theoretically, the findings for this study offer useful knowledge and insights for future researchers. For example, the current study confirms the applicability of social exchange theory (SET). Many previous studies revealed that SET is one of the most influential theories in organizational behaviour. As employees spend their much time at their lives at work. They need some exchange for their effort such as training, development, reward and recognition and so on. Accordingly, the impact of employee engagement to an organization not only can improve organizational effectiveness but can also increase work well-being (Jha, Potnuru, Sareen \& Shaju, 2019; Kataria, Rastogi \& Garg, 2013). In the matter of practice, the findings have proven to the management of the banking sector in which they can apply two independent variables such as transformational leadership and training and development to enhance employee engagement in a financial institution in Kuala Lumpur. Top management can also take necessary steps to create better engagement and prevent attrition among employees. For example, organizations need to take advantage of their leaders' transformational style to boost engagement among staff. Other than that, the findings also provide valuable information for human resource management in the organization as they improve employee performance. Top management is also implied to focus on recruiting managers with transformational style to improve employee engagement.

\section{References}

Afroz, N. N. (2018). Effects of Training on Employee Performance - A Study on Banking Sector, Tangail Bangladesh. Global Journal of Economics and Business, 4(1), 111-124.

Aguinis, H., and Kraeger, K. (2009). Benefits of Training and Development for Individuals and Teams, Organizations, and Society. Annual Review of Psychology, 60, 451-474. 
Aktar, A. \& Pangil, F. (2018). Mediating role of organizational commitment in the relationship between human resource management practices and employee engagement: Does black box stage exist? International Journal of Sociology and Social Policy. 38, 606-635.

Anitha, J., (2014). Determinants of employee engagement and their impact on employee performance, International Journal of Productivity and Performance Management, 63(3), 308 - 323.

AON Hewitt. (2018). Trends in global employee engagement. Retrieved from https://www.aonhewitt.com.au/Home/Resources/Reports-and-research/2017-Trends-in-Global-EmployeeEngagement-report.

Avolio, B. J., \& Bass, B. M. (2004). Multifactor leadership questionnaire manual and sampler set (3rd ed.). Palo Alto, CA: Mind Garden

Bakker, A.B. and Schaufeli, W.B. (2008), "Positive organizational behavior: engaged employees in flourishing organizations", Journal of Organizational Behavior: The International Journal of Industrial, Occupational and Organizational Psychology and Behavior, 29(2), 147-154.

Balwant, P. T., Mohammed, R. and Singh, R. (2019). Transformational leadership and employee engagement in Trinidad's service sector: The role of job resources. International Journal of Emerging Markets. 15(4), 691-715.

Bass, B.M. and Riggio, R.E. (2006), Transformational Leadership, (2nd ed.). Erlbaum, Mahwah, NJ.

Botero, I. C., \& Van Dyne, L. (2009). Employee voice behavior: Interactive effects of LMX and power distance in the United States and Colombia. Management Communication Quarterly, 23(1), 84-104.

Bui, H. T. M., Zeng, Y. \& Higgs, M. (2017). The role of person-job fit in the relationship between transformational leadership and job engagement. Journal of Managerial Psychology. 32(5), 373-386.

Chadha, D. (2018). A Study of Training and Development Practices in Service Sector in Relation to Employee Engagement across Delhi and NCR. International Journal of Human Resource Development and Management, 8(1), 111. Retrieved from https://www.ripublication.com/ijhrdm18/ijhrdmv8n1_01.pdf.

Delery, J.E. and Doty, D.H. (1996) Modes of Theorizing in Strategic Human Resource Management: Test of Universalistic, Contingency, and Configurational Performance Predictions. Academy of Management Journal, 39, 802-835.

Detert, J. R., \& Burris, E. R. (2007). Leadership behavior and employee voice: Is the door really open? Academy of Management Journal, 50(4), 869-884.

Ganesan, J. \& Azli, M. Z. (2017). Determinants of Employee Engagement in the Malaysian Health Care Industry. World Applied Sciences Journal. 35(10). 2180-2186.

Gibson, J.L., Ivancevich, J.M, Donnely, J.H \& Konopaske R. (2012). Organizations. Behavior, Structure, processes. Boston: McGraw-Hill.

Guilford, J. P., \& Fruchter, B. (1973). Fundamental statistics in psychology and education (5th ed.). McGraw-Hill.

Harter, J. K., Schmidt, F. L., \& Hayes, T. L. (2002). Business-unit-level relationship between employee satisfaction, employee engagement, and business outcomes: A meta-analysis. Journal of Applied Psychology, 87(2), 268-279..

Hoon Song, J., Kolb, J. A., Hee Lee, U., \& Kyoung Kim, H. (2012). Role of transformational leadership in effective organizational knowledge creation practices: Mediating effects of employees' work engagement. Human Resource Development Quarterly, 23(1), 65-101.

Jha, N., Potnuru, R. K. G., Sareen, P. \& Shaju, S. (2019). Employee voice, engagement and organizational effectiveness: a mediated model. European Journal of Training and Development. 43(7/8).

Kahn, W.A. (1990), "Psychological conditions of personal engagement and disengagement at work", Academy of Management Journal, 33, 692-724.

Kataria, A., Rastogi, R. \& Garg, P. (2013), “Organizational effectiveness as a function of employee engagement", South Asian Journal of Management, 20(4), 56.

Luthans, F., \& Peterson, S. (2002). Employee engagement and manager self-efficacy. Journal of Management Development, 21(5), 376-387.

Macey, W. H., \& Schneider, B. (2008). The meaning of employee engagement. Industrial and Organizational psychology, 1(1), 3-30.

Mansor, Z. D, Jaharudin, N. S., Nata, N. M. (2018). Employee Engagement in Public Organizations in Malaysia. Proceeding of the 5th International Conference on Management and Muamalah 2018 (ICoMM 2018). $258-272$.

Maslach, C., Schaufelli, W.B. and Leiter, M.P. (2001), “Job burnout”, Annual Review of Psychology, 52, $397-422$.

Puni, A., Mohammed, I. \& Asamoah, E. (2018). Transformational leadership and job satisfaction: the moderating effect of contingent reward. Leadership and Organization Development Journal. 
Purcell, J., Kinnie, N., Hutchinson, S., Rayton, B., and Swart, J. (2003), Understanding the People and Performance Link: Unlocking the Black Box, London: CIPD.

Rafferty, A. E. \& Griffin, M. A. (2004). Dimensions of transformational leadership: Conceptual and empirical extensions. The Leadership Quarterly, 15(3), 329-354.

Rees, C., Alfes, K. and Gatenby, M. (2013), "Employee voice and engagement: connections and consequences", The International Journal of Human Resource Management, 24(14), 2780-2798.

Reissner, S. \& Pagan, V. (2013). Generating employee engagement in a public-private partnership: management communication activities and employee experiences. International Journal of Human Resource Management, 24(14). 2741-2759.

Saks, A.M. (2006), “Antecedents and consequences of employee engagement”, Journal of Managerial Psychology, 21(7), 600-619.

Sanneh, L., \& A.Taj, S. (2015). Employee Engagement in the Public Sector: A Case Study of Western Africa. International Journal of Human Resource Studies.

Schaufeli, W., Salanova, M., Gonzalez-Roma, V. and Bakker, A. (2002). The Measurement of Engagement and Burnout: A Two Sample Confirmatory Factor Analytic Approach. Journal of Happiness Studies, 3, 71-92.

Shahid, A. (2019). The Employee Engagement Framework: High Impact Drivers and Outcomes. Journal of Management Research. 11(2).

SheeMun, Y., Suhaimi, M. N., Abdullah, S. S., Rahman, S. A., \& Mat, N. K. N. (2013). Employee engagement: A study from the private sector in Malaysia. Human Resource Management Research, 3(1), 43-48.

Sibanda, P., Muchena, T., \& Ncube, F. (2014). Employee Engagement and Organizational Performance in a Public Sector Organisation in Zimbabwe. International Journal of Asian Social Science, 4(1), 89-99.

Siddiqui, D. A. and Sahar, N. U. (2019). The Impact of Training \& Development and Communication on Employee Engagement a Study of Banking Sector. Business Management and Strategy, 10(1). 23-40.

Tannenbaum, S.I., Mathieu, J.E., Salas, E. and Cohen, D. (2012), “Teams are changing: are research and practice evolving fast enough?", Industrial and Organizational Psychology, 5(1), 2-24.

Van Dyne, L. and Le Pine, J.A. (1998), “Helping and voice extra-role behavior: evidence of construct and predictive validity", Academy of Management Journal, 41(1), 108-119.

AlZgool, M. R. H., Ahmed, U., Pahi, M. H., \& Ammar, A. (2020). COVID-19 and Work Engagement: Understanding the Nexus of Leaders Emotional Intelligence, Self-efficacy and Resilience in the Banking Sector of Bahrain. Revista Argentina de Clínica Psicológica, 29(3), 568.

Ahmed, U. (2019). Understanding Work Engagement: Simplified Literature Review for Early Scholars. Ahmed, U. Understanding work engagement: Simplified literature review for early scholars. Humanities and Social Sciences Review, 7(5), 1073-1081.

Pahi, M. H., Hamid, K. A., Ahmed, U., \& Umrani, W. A. (2015). The unresolved dilemma of leadership-commitment relationship: A proposed framework. Business and Economics Journal, 7(1), 2-7.

Tangirala, S., Kamdar, D., Venkataramani, V., \& Parke, M. R. (2013). Doing right versus getting ahead: The effects of duty and achievement orientations on employees' voice. Journal of Applied Psychology, 98(6), 1040-1050.

Ahmed, U., Isa, N. M., Majid, A. H. A., Zin, M. L. M., \& Amin, B. M. (2017). Towards understanding work engagement: can HR really buffer HR? Test of a moderated model. International Journal of Economic Research, 14(20), 1-18.

Ahmed, U., Abdul Majid, A. H., \& Mohd Zin, M. (2016). Construct validation of 17-item Utrecht University work engagement scale amongst the white collar employees of Malaysian Universities. International Journal of Academic Research in Business and Social Sciences, 6(5), 306-312.

Shimazu, A., Schaufeli, W. B., Kosugi, S., Suzuki, A., Nashiwa, H., Kato, A., ... \& Kitaoka-Higashiguchi, K. (2008). Work engagement in Japan: validation of the Japanese version of the Utrecht Work Engagement Scale. Applied Psychology, 57(3), 510-523.

Sekaran, U., \& Bougie, R. (2016). Research methods for business: A skill building approach. John Wiley \& Sons.

(C) 2021 by the author(s). Published by Annals of Contemporary Developments in Management \& HR (ACDMHR), under the terms and conditions of the Creative Commons Attribution (CC BY) license which can be accessed at http://creativecommons.org/licenses/by/4.0/. 